\title{
Role Model a Tool towards Cross Training in Improving Team Performance
}

\author{
S.Sridhar, V.M .Ponniah
}

\begin{abstract}
Manufacturing (Globally and in India) is saturating and there are no breakthrough innovations and hence sales is under pressure. While we wait for innovation new products to take over, the manufacturing is focusing for competitiveness and optimize the resources.
\end{abstract}

TPM (Total Productive Maintenance) is an important tool to bring the change, the tool ensures that by total participation and by effective implementation of TPM concepts Resource optimization can be achieved. There are $3464^{1}$ Companies in the world and $369^{2}$ in India who have been certified by JIPM (Japan Institute of planned maintenance) for effective use of TPM and achieving the change in the form of results. 7 plants has been certified in Hindustan Coca-Cola Beverages Pvt Ltd.

These companies are building High performance teams to move TPM to next levels. The challenge is labour flexibility and hence Labour flexibility is important issue in the design and development of "High performance teams ".

TPM has many training tools and focuses more on relay training, Cross training builds on relay training. Hindustan Coca-Cola beverages pvt ltd has used the cross training in 2 plants and in 4 lines.

A group of 15 operators were formed as Shilpakar (Architect ), they were positive, influencing others and some of them were individualistic and not team player, some of them were also union leaders. This team was rejuvenated with their self-esteem, and with right attitudes, Team work, Sincerity and discipline which was hidden got exposed and blossomed.

One of the executive (coach) lead the activities with leadership appreciation, this followed with Multi Skilling and bought team-work, self-respect and trust within the team. The team also had social side of family trekking and Training the Street vendor in FSSAI (Food safety \& authorities of India) requirements. This team then was adequately recognised, rewarded and had achieved special status in the plant.

Looking at this team, next set of operators had aspirations and were readily agreed to learn from this role model team. The role model team could train 4 more groups. Executives were mentors and reviewed the progress and review the progress of the new team. Once done they were recognised and appreciated.

Index Terms: Role Model, Relay training, Heuristic, Transformational leadership, Team working, High Performance teams, Happy and satisfaction leading to motivation.

\section{INTRODUCTION}

Successful implementation of TPM lead to improvement in productivity and builds culture of motivated employees, this is achieved with ownership of upkeeping the equipment's

Revised Manuscript Received on July 22, 2019.

S.Sridhar, SRM School of Management, Kattankulathur, Tamil Nadu, India.

Dr V.M .Ponniah, SRM School of Management, Kattankulathur, Tamil Nadu, India. behavioural training programs - they were then rewarded with the

in its basic condition. Therefore, equipment maintenance is an indispensable function in a manufacturing enterprise. In this highly competitive environment, focus by manufacturing organizations should be toward proper maintenance. This will help in moving towards optimal maintenance cost and build reliability in the system..(Singh et al., 2008).(Abhishek, Rajbir and Harwinder 2014).

Labour flexibility is an important issue in the design and development of "High performance teams ". This is required when Manufacturing is saturating and there are no breakthrough innovations in manufacturing and hence sales is under pressure. While we wait for innovation new products to take over, the manufacturing is looking for competitiveness and optimize the resources .(Jannes Slomp, Eric Molleman 2002).

There are alternative systems for managing employees and organizingtheirwork might which will lead to superior employee performance and, in turn, superior organizational performance. The focus is building ownershipstructures, involvement and team work, this in turn will lead to superior employee performance (Webb and Webb 1965 inthe U.K., orCommons 1970 in the U.S.).

We need flexible, high performance team, with continued energy of learning and performing well.This is done through formation of SMART ( Self-managed autonomous and reliable team ). This is achieved with the combination of TPM and with behavioural changes in the team.

Change is difficult and very slow processes, many times it fails and takes back seat, hence pilot teams called Shilpakar ( Indian word stating the person who is creator or architect who normally makes idols for God ). This team is basically the role model team . The benefit of this is twofold - create and make a visible change for others to see and the team trained will train new teams by relay training.

\section{REVIEW OF LITERATURE}

The challenges which the manufacturing are facing can be overcome by implementing TPM (Total Productive Maintenance), The gain is optimum use of resources, highly motivated workforce with than improved efficiency, this can be achieved by Education and training pillar which uses lots of relay training. Relay training are effective, easier and at reduced training cost. (Singh et al., 2008).(Abhishek, Rajbir and Harwinder 2014). 
High performance teams improves flexibility and in competitive world, is the effective and lean approach of organisation structure, Cross training can be highly motivating and if done wrong can be demotivating (Jannes slomp, Erric 2002). This reduces idle time and helps in keeping operators in self-challenging environment, it needs proper design and execution and first-time right is very important hence Role model team for cross training.

Transfer of training is better when done by cross training, effective and faster. Peer relationship improves, when one team trains the other. Role model team is the best way. (Iliyasu Shiyanbade Najeemdeen, Bello Taofik Abidemi and Peter Ugochukwu Anuforo (2018).

\section{SELECTION AND DEVELOPING ROLE MODEL TEAMS}

Selection of members for the high-performance teams need to be thoughtful and strategic. These are the first change agents and needs to be carefully selected. We took the criteria of persons who are influencing or creates voice, noise in the plant. In this we get two types of people one truly motivated and always trying to do good for the organisations and have self-improvement, the other who creates noises and gains attentions.

TPM has a tool creates lots of positive cultures and increases visibility of operator's contributions, thereby bringing ownership and involvement, which ultimately helps each of the operator to gain self-respect in the organisation. One of principal motivator factor is Kaizens (Japanese name for improvement or small innovations ). There many operators who wants to perform well and get recognised and Kaizens is the first successes towards culture change. Many members who had done kaizens and got recognised are selected.
The Nosie creators are equally important, they come in way between any change hence members from Union and key persons who voice the concern first and most are selected. Initially it was difficult to handle and mould them, but later these were star performers in the SMART team.

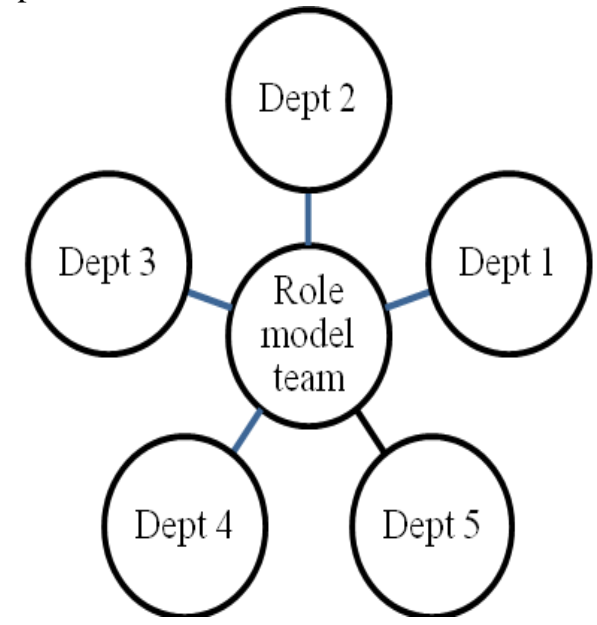

Figure 1: shows that members from each department is selected, care is taken that minimum one member from each department is a member in the Role model.

\section{DEVELOPING TRAINING PLAN AND STRATEGY}

A strategy is made to mould the role model team with adequate care taken to have rewards and recognitions at frequent intervals.

The first challenge is to bring back the self-esteem. The author is of the opinion that every person has self-esteem, it's not polished or hidden because of his/her upbringing. The first goal is to rejuvenate the same and celebrate.

Table 1: Personal role model exercise is, each one has to identify one person who has become a great personality having the three qualities -Team work, discipline and sincerity and learn from history, books, web etc.

\begin{tabular}{|l|l|l|}
\hline Sno & Challenges & Convincing points \\
\hline $\mathbf{1}$ & I do not desire to grow from Optr. category & Social pressure and family pressure \\
\hline $\mathbf{2}$ & In disciplined & Meeting target delay not even a sec \\
\hline $\mathbf{3}$ & No trust & Build and appreciate each other \\
\hline $\mathbf{4}$ & No team work & Show power of team \\
\hline $\mathbf{5}$ & Learning a waste & Learning a treasure \\
\hline $\mathbf{6}$ & Waste of time & Important to invest for future \\
\hline $\mathbf{7}$ & No Successes & Small Successes \\
\hline $\mathbf{8}$ & No recognitions and appreciation & Recognitions and appreciation \\
\hline $\mathbf{9}$ & Low self-respect & Gain self-respect \\
\hline $\mathbf{1 0}$ & Low self esteem & Rejuvenate self esteem \\
\hline
\end{tabular}

The potential of these personality needs to be self-inculcated which was already in existence with the role model team members, only nurtured and as the time progressed their belief increased and reinforced.

\section{A. Power of role model to rejuvenate self-esteem}

Developing the role model Team: Each team member was asked to identify one role model who had influenced from childhood and there was an ambition to become like that person, but time and circumstances were difficult.
After identifying each member was asked to make a visual chart with his name and role model personality - photo and some brief details about the role model eg date birth education and achievements. 
The members were asked to go and study how the enablers such as Teamwork discipline and sincerity helped him/her to achieve the status. Stories, case studies were collected and explained in the chart paper - this was a visual tool for everyone to see.

During every training program each member has to share stories how his/her role model used the three attitudes. This was repeated many times and each time it was seen or explained it reinforced the behaviour of the individual.

Slowly the qualities were embodied, and behaviour change was observed. This change was appreciated by leadership and rewarded. This was the first transformation of the role model team.

\section{B. Celebration of change}

After the change in the behaviours the same was demonstrated to leadership and visitors, each time the team got appreciation. The trust and team work was reinforced.The team was also appreciated by their own peer group and for others the desire was created.

Request starts coming voluntarily to have the second batch for similar training. This should be encouraged, and new teams formed, training to start at the earliest

To mark the successes, big life size posters are kept in strategic locations for them to remind every day when they come to work.

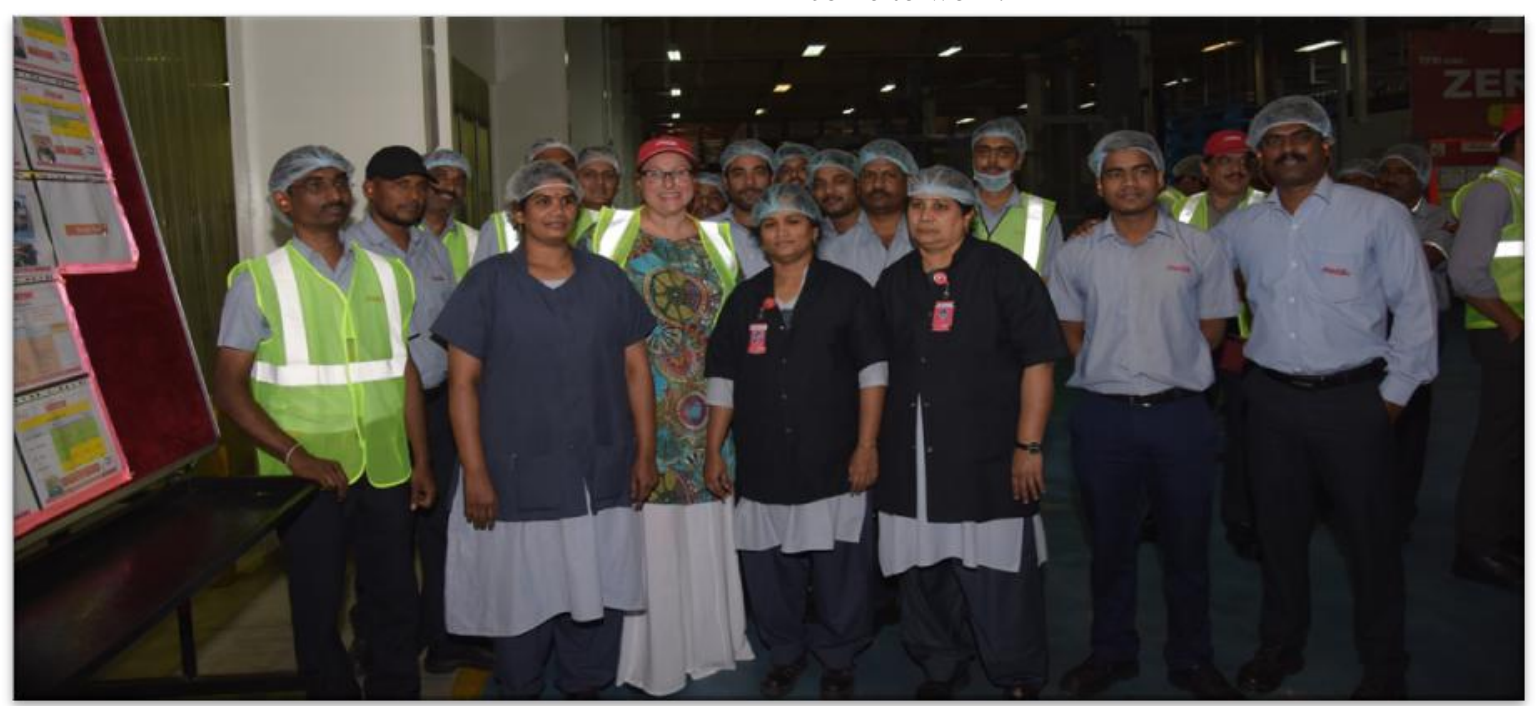

CEO of Hindustan Coca- Cola witnessing the change after cross training and appreciating the Role model team. This adds aspiration on the rest of associates

\section{Behavioural trainings}

Behavioural training calendar and completion of the program was with the help of large visual boards. The training then was imparted to the role model team, this was also used to influence others. Training was given for Inculcating Team-work, discipline and sincerity.

These are supported by soft skill too. The same is displayed for everyone to see, as each training is completed and added in the visual display the motivation in the team increases.

There is no standard way of trainings, focus should be ensured fun is part of training. This is a continuing activity and is the key responsibility for $\mathrm{CHO}$ Chief happiness officer.

\section{Multi skill trainings}

Cross training is very effective in Multi skill, as learning from superiors calls for resistance to learn, while when peer groups teaches its readily accepted, this is a true form of relay training or "I learn I train "programs helps in building relationship and respect between operators.
This also removes from job boring, working and doing the same job over the years, becomes monotonous and in some cases, it reduces efficiencies.

The multi skill has the other benefits, helps in career building, Someday the operators can take role of executive or manager in the same organisation or in some other organizations.

Skilled labour is shortage globally and in India too. It's going to be worse not better.

\section{E. Ownership to own the line.}

As the training progress, we could see one by one activity will be handled by team, the same needs to be appreciated. This is the key deliverables.

Pride and passion are seen and demonstrated many-many times.

Once role model team reaches this stage its is ready for cross trainings.

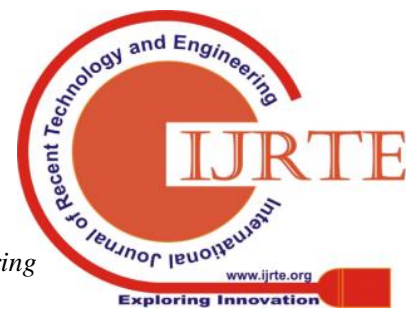




\section{F. Presentations to leadership and visitors.}

To reinforce the successes and motivate the role model team, presentation to leadership, their acknowledgement and acceptance is very important.

\section{G. Celebration of Pride and passion.}

Small -Small celebrations and reward system is important, this acknowledges the work done motivates to move forward.

Each individual needs recognitions and motivation, hence this should be done at very short intervals, The value of prize/ reward is not important, the respect management gives to operators is important.

\section{H. Role model team as "mentors"}

Building role model teams needs very dedicated mentors, The Mentors should have very close interactions with his team, initial days more time is to be spent and all queries to be answered honestly. There may be times when convincing may be required and may not happen in one sitting, it need multiple rounds and discussions.

The success of role model team depends on the mentors, when this role model teams becomes a trainer to another team, he/she acts as a mentor.

\section{Cross training.}

Once the role model team is ready it acts as a mentor and starts building other teams. Cross trainings are faster and more effective. All the steps needs used for building role model team should be used and no short cuts.

Reward and recognitions is important.

\section{J. Team performance}

Plant performance has sustained and improved after training, This has happened for two consequent years in two lines.

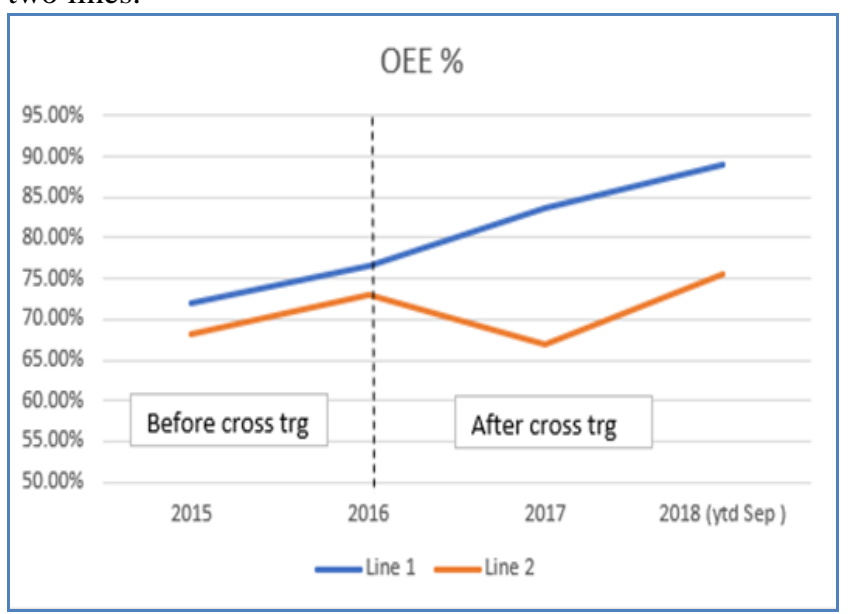

\section{K. Audit by JIPM (Japanese institute of planned maintenance) auditors.}

The processes of use of role model team for cross trainings, has been appreciated, they had conveyed that the same should be practised in other plants.

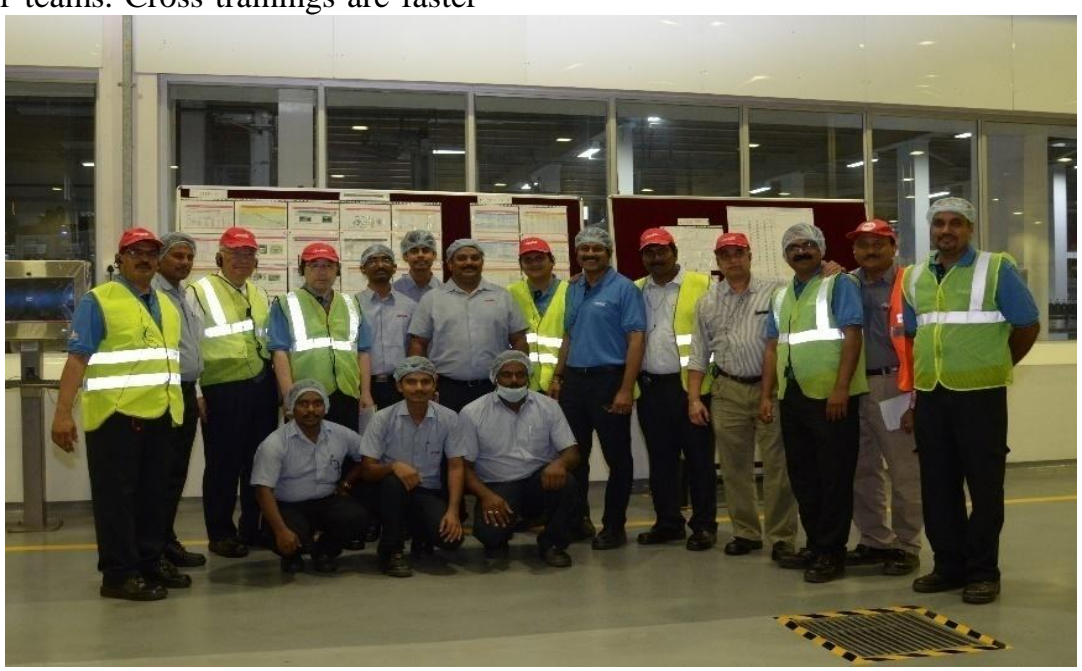

JIPM Auditors appreciating cross trainings in 2018

\section{RESEARCH DESIGN}

The type of Research design planned and executed was Descriptive type, with a data Collection were subjected toQuestionnaires method, Questionaries' was subjected to role model team and their superiors to verify the effectiveness. In each of these the sample size was taken as 40 and 59, the sample was tested in the Pune plant of Hindustan Coca- Cola beverages Pvt ltd. To analysis the Statistical tools were used. Analysis was done to reduce the variables which were prominent. SPSS 23 was used.

\section{A. Sample size and Data Collection}

The sample size was 40 for role model team and for staff 59, Sample was considered all members of role model team and the same is verified for meeting the deliverables by executives, managers and Factory head.

The survey questions are classified in five categories, The survey was done 1-5 scale:

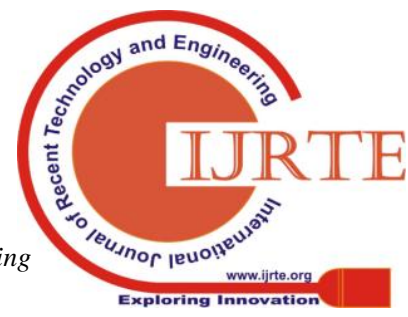



A: Rejuvenate Self Esteem
B: Soft behavioural trainings
C: Multi Skill
D: Support by Mentor

E: Social interactions

F: Reward and recognitions

\begin{tabular}{|c|c|c|c|}
\hline \multicolumn{4}{|c|}{ Table 2: } \\
\hline Sno & Question for role model team & Sno & $\begin{array}{c}\text { Question for staff supervising the team and } \\
\text { effectiveness of CT }\end{array}$ \\
\hline $\mathrm{A}$ & Rejuvenate Self esteem & $\mathrm{A}$ & Rejuvenate Self esteem \\
\hline A1 & $\begin{array}{l}\text { TPM Certified operators } \\
\text { created TDS - team work } \\
\text { sincerity and discipline }\end{array}$ & A1 & $\begin{array}{l}\text { I could see positive change in other team by } \\
\text { observing team work, discipline and } \\
\text { sincerity }\end{array}$ \\
\hline A2 & $\begin{array}{l}\text { Benefits of Role model } \\
\text { approach }\end{array}$ & A2 & $\begin{array}{l}\text { I could see no change in pride transfer from } \\
\text { Role model team to other team }\end{array}$ \\
\hline A3 & $\begin{array}{l}\text { Benefit of My machine } \\
\text { concepts }\end{array}$ & A3 & $\begin{array}{l}\text { I could see positive change in team's } \\
\text { attitude by observing role model team }\end{array}$ \\
\hline A4 & Team work improved & A4 & $\begin{array}{l}\text { I could see no increase in respect in the } \\
\text { other team after cross training }\end{array}$ \\
\hline A5 & Trust in team improved & A5 & $\begin{array}{l}\text { On the whole role model team has enabled } \\
\text { other teams to embrace satisfaction within } \\
\text { themselves }\end{array}$ \\
\hline & 1) & & 2) \\
\hline $\mathrm{B}$ & Soft / Behavioural trainings & $\mathrm{B}$ & Soft / Behavioural trainings \\
\hline B1 & Helps in listening skills & $\mathrm{B} 1$ & $\begin{array}{l}\text { I could see listening skills in other teams } \\
\text { improved by seeing the role model team }\end{array}$ \\
\hline B2 & Helps in presentation skills & B2 & $\begin{array}{l}\text { I could not see improvement in presentation } \\
\text { skills improvement in other teams }\end{array}$ \\
\hline B3 & Build confidence & B3 & $\begin{array}{l}\text { I could see role mode team has influenced } \\
\text { confidence in other teams }\end{array}$ \\
\hline B4 & learning makes happy & B4 & $\begin{array}{l}\text { I could not see increased level of happiness } \\
\text { in the other teams }\end{array}$ \\
\hline B5 & $\begin{array}{l}\text { Communication inside the } \\
\text { team improved }\end{array}$ & B5 & $\begin{array}{l}\text { On the whole positive change is seen in } \\
\text { influence of role model team in building } \\
\text { Communication in other teams }\end{array}$ \\
\hline & 3) & & 4) \\
\hline $\mathrm{C}$ & Multi Skill & $\mathrm{C}$ & Multi Skill \\
\hline $\mathrm{C} 1$ & $\begin{array}{l}\text { New Technical learnings } \\
\text { make me happy }\end{array}$ & $\mathrm{C} 1$ & $\begin{array}{l}\text { I could see transfer by role model team to } \\
\text { other teams on new technical learnings } \\
\text { makes the team members happy }\end{array}$ \\
\hline $\mathrm{C} 2$ & $\begin{array}{l}\text { learn and teach helps in } \\
\text { building self-respect }\end{array}$ & $\mathrm{C} 2$ & $\begin{array}{l}\text { I observed that self-respect of role model } \\
\text { team improved by cross training }\end{array}$ \\
\hline $\mathrm{C} 3$ & $\begin{array}{l}\text { Multi Skill helps in team } \\
\text { work }\end{array}$ & $\mathrm{C} 3$ & $\begin{array}{l}\text { I could see positive change in team work } \\
\text { with the support of role model team. }\end{array}$ \\
\hline $\mathrm{C} 4$ & Will help me in my growth & $\mathrm{C} 4$ & $\begin{array}{l}\text { Role model team is not able to influence the } \\
\text { relationship of Multiskill helps in the } \\
\text { growth of individuals in other teams }\end{array}$ \\
\hline & & & 5) \\
\hline $\mathrm{D}$ & Support by Mentor & $\mathrm{D}$ & Support by Mentor \\
\hline D1 & Mentor guidance helped me & D1 & $\begin{array}{l}\text { Role model team could not guide other } \\
\text { teams as a Mentor }\end{array}$ \\
\hline D2 & $\begin{array}{l}\text { Mentor feedback helped me } \\
\text { in correcting my gaps }\end{array}$ & D2 & $\begin{array}{l}\text { Mentor (Role model team ) feedback did } \\
\text { not help other teams. }\end{array}$ \\
\hline D3 & Mentor motivated me & D3 & $\begin{array}{l}\text { Mentor ( role model team ) motivated the } \\
\text { other teams }\end{array}$ \\
\hline D4 & $\begin{array}{l}\text { Mentor reviewed my } \\
\text { progress }\end{array}$ & D4 & $\begin{array}{l}\text { I could see effective review mechanism by } \\
\text { Mentor to other team for their progress }\end{array}$ \\
\hline & & & $6)$ \\
\hline $\mathrm{E}$ & Social interactions & $\mathrm{E}$ & Social interactions \\
\hline E1 & $\begin{array}{l}\text { Weekly trekking helped to } \\
\text { understand each other }\end{array}$ & E1 & $\begin{array}{l}\text { I could observe Weekly trekking helped to } \\
\text { understand role model teams and other } \\
\text { teams }\end{array}$ \\
\hline
\end{tabular}


Role Model a Tool towards Cross training in improving team performance

\begin{tabular}{|c|c|}
\hline $\mathrm{E} 2$ & $\begin{array}{l}\text { Plantation of trees increased } \\
\text { my pride }\end{array}$ \\
\hline E3 & $\begin{array}{l}\text { Participation in FSSAI road } \\
\text { show drive motivated me }\end{array}$ \\
\hline $\mathrm{F}$ & Reward and recognitions \\
\hline $\mathrm{F} 1$ & $\begin{array}{l}\text { Presentation to visitors } \\
\text { motivated me }\end{array}$ \\
\hline $\mathrm{F} 2$ & $\begin{array}{l}\text { Presentation to Auditors } \\
\text { motivated me }\end{array}$ \\
\hline F3 & $\begin{array}{l}\text { Congratulations from } \\
\text { colleagues motivated me }\end{array}$ \\
\hline $\mathrm{F} 4$ & $\begin{array}{l}\text { My line performance } \\
\text { motiavtes me }\end{array}$ \\
\hline F5 & $\begin{array}{l}\text { Clean workplace motivates } \\
\text { me }\end{array}$ \\
\hline
\end{tabular}

\begin{tabular}{|l|l|}
\hline E2 & $\begin{array}{l}\text { I could see no relationship of pride with } \\
\text { Role model team working with other teams } \\
\text { on Plantation of trees . }\end{array}$ \\
\hline E3 & $\begin{array}{l}\text { I could see Leadership visits, Visitors } \\
\text { comments and Audits Participation helps } \\
\text { interaction with Role model team and other } \\
\text { teams }\end{array}$ \\
\hline F & Reward and recognitions \\
\hline F1 & $\begin{array}{l}\text { I could see the efforts of role model team in } \\
\text { cross training on Presentation skill to other } \\
\text { teams }\end{array}$ \\
\hline F2 & $\begin{array}{l}\text { I could see negative change in motivation } \\
\text { levels when Presentation done by team } \\
\text { members to Auditors. }\end{array}$ \\
\hline F3 & $\begin{array}{l}\text { Congratulations/ appreciation by Role } \\
\text { model team motivates the other teams }\end{array}$ \\
\hline F4 & $\begin{array}{l}\text { Team members are motivated when line } \\
\text { performance is above business target }\end{array}$ \\
\hline F5 & $\begin{array}{l}\text { Role model team has influenced the other } \\
\text { teams that Clean workplace motivates all }\end{array}$ \\
\hline
\end{tabular}

Few of the above questionnaire are negative in nature and the score is reversed in SPSS.

\section{B. Analysis}

Table 3 shows one sample analysis for example:

SPSS V.23 was used for analysis of all the variables contributing towards building role model. This analysis

Table 3:

\begin{tabular}{|l|r|r|r|r|r|}
\hline & \multicolumn{1}{c|}{ A1 } & \multicolumn{1}{c|}{ A2 } & \multicolumn{1}{c|}{ A3 } & \multicolumn{1}{c|}{ A4 } & \multicolumn{1}{c|}{ A5 } \\
\hline \multicolumn{1}{c|}{ Valid } & 40 & 40 & 40 & 40 & 40 \\
Mean & 0 & 0 & 0 & 0 & 0 \\
Std. Error of Mean & 4.225 & 4.150 & 4.550 & 4.475 & 4.400 \\
Median & .1160 & .1412 & .1071 & .1386 & .1377 \\
Mode & 4.000 & 4.000 & 5.000 & 5.000 & 5.000 \\
Std. Deviation & 4.0 & 5.0 & 5.0 & 5.0 & 5.0 \\
Variance & .7334 & .8930 & .6775 & .8767 & .8712 \\
Skewness & .538 & .797 & .459 & .769 & .759 \\
Std. Error of Skewness & -.384 & -.536 & -1.232 & -2.083 & -1.636 \\
Kurtosis & .374 & .374 & .374 & .374 & .374 \\
Std. Error of Kurtosis & -1.014 & -.976 & .314 & 5.219 & 4.786 \\
Range & .733 & .733 & .733 & .733 & .733 \\
Minimum & 2.0 & 3.0 & 2.0 & 4.0 & 5.0 \\
Maximum & 3.0 & 2.0 & 3.0 & 1.0 & 1.0 \\
\hline & 5.0 & 5.0 & 5.0 & 5.0 & 6.0 \\
\hline
\end{tabular}

The same variables were subjected to correlations study. 
International Journal of Recent Technology and Engineering (IJRTE)

ISSN: 2277-3878, Volume-8 Issue-2S6, July 2019

Table 4:

Correlations

\begin{tabular}{|c|c|c|c|c|c|c|}
\hline & & $\mathrm{A} 1$ & $\mathrm{~A} 2$ & A3 & A4 & A5 \\
\hline \multirow[t]{3}{*}{$\mathrm{A} 1$} & Pearson Correlation & 1 & $.456^{* *}$ & $.519^{* *}$ & $.388^{*}$ & $.377^{\star}$ \\
\hline & Sig. (2-tailed) & & .003 & .001 & .013 & .016 \\
\hline & $\mathrm{N}$ & 40 & 40 & 40 & 40 & 40 \\
\hline \multirow[t]{3}{*}{ A2 } & Pearson Correlation & $.456^{* *}$ & 1 & $.581^{\star *}$ & $.398^{*}$ & $.415^{* *}$ \\
\hline & Sig. (2-tailed) & .003 & & .000 & .011 & .008 \\
\hline & $\mathrm{N}$ & 40 & 40 & 40 & 40 & 40 \\
\hline \multirow[t]{3}{*}{ A3 } & Pearson Correlation & $.519^{* *}$ & $.581^{\star *}$ & 1 & $.412^{* \star}$ & $.443^{* *}$ \\
\hline & Sig. (2-tailed) & .001 & .000 & & .008 & .004 \\
\hline & $\mathrm{N}$ & 40 & 40 & 40 & 40 & 40 \\
\hline \multirow[t]{3}{*}{ A4 } & Pearson Correlation & $.388^{\star}$ & $.398^{*}$ & $.412^{* *}$ & 1 & $.718^{* *}$ \\
\hline & Sig. (2-tailed) & .013 & .011 & .008 & & .000 \\
\hline & $\mathrm{N}$ & 40 & 40 & 40 & 40 & 40 \\
\hline \multirow[t]{3}{*}{ A5 } & Pearson Correlation & $.377^{\star}$ & $.415^{\star *}$ & $.443^{\star *}$ & $.718^{* \star}$ & 1 \\
\hline & Sig. (2-tailed) & .016 & .008 & .004 & .000 & \\
\hline & $\mathrm{N}$ & 40 & 40 & 40 & 40 & 40 \\
\hline
\end{tabular}

**. Correlation is significant at the 0.01 level (2-tailed).

*. Correlation is significant at the 0.05 level (2-tailed).

KMO and Bartlett's Test

\begin{tabular}{|c|r|}
\hline Kaiser-Meyer-Olkin Measure of Sampling Adequacy. & .763 \\
Bartlett's Test of Sphericity $\quad$ Approx. Chi-Square & 67.054 \\
& df \\
Sig. & .000 \\
\hline
\end{tabular}

Total Variance Explained

\begin{tabular}{|l|r|r|r|r|r|r|}
\hline \multirow{2}{*}{ Component } & \multicolumn{3}{|c|}{ Initial Eigenvalues } & \multicolumn{2}{c|}{ Extraction Sums of Squared Loadings } \\
\cline { 2 - 7 } & Total & \% of Variance & Cumulative \% & Total & \% of Variance & Cumulative \% \\
\hline 1 & 2.886 & 57.719 & 57.719 & 2.886 & 57.719 & 57.719 \\
3 & .872 & 17.433 & 75.151 & & & \\
4 & .553 & 11.070 & 86.221 & & & \\
5 & .410 & 8.195 & 94.416 & & & \\
\hline
\end{tabular}

Extraction Method: Principal Component Analysis. 

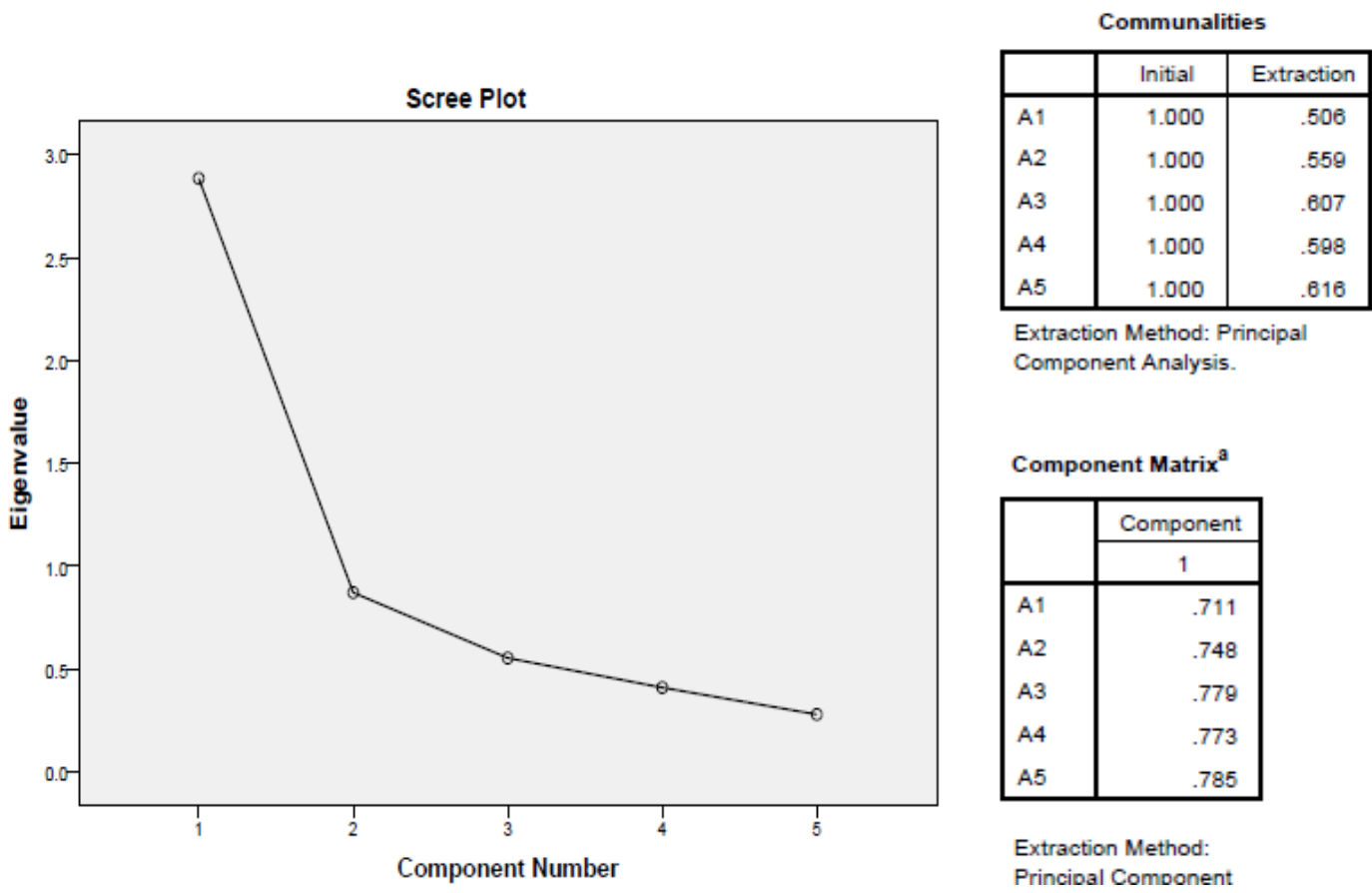

All the variables one set of Role model team and the other of Staff correlating the effect of variable contributing towards training and its effectiveness.

The summary is as follows:

\begin{tabular}{|c|c|c|c|c|c|}
\hline \multirow{2}{*}{$\begin{array}{l}\mathrm{S} \\
\mathrm{no}\end{array}$} & \multirow[t]{2}{*}{ Variable } & \multicolumn{2}{|c|}{ Role model team } & \multicolumn{2}{|c|}{ Staff } \\
\hline & & Variable selected & Eigenvalues & Variable selected & Eigenvalues \\
\hline 1 & $\begin{array}{l}\text { Rejuvenate } \\
\text { Self-esteem A1-A5 }\end{array}$ & $\begin{array}{l}\text { A5: Trust in team } \\
\text { improved }\end{array}$ & $57.79 \%$ & $\begin{array}{l}\text { A5:On the whole } \\
\text { role model team } \\
\text { has enabled other } \\
\text { teams to embrace } \\
\text { satisfaction within } \\
\text { themselves }\end{array}$ & $52.811 \%$ \\
\hline 2 & $\begin{array}{l}\text { Soft / Behavioural } \\
\text { trainings B1-B5 }\end{array}$ & $\begin{array}{l}\text { B5: Communication } \\
\text { inside the team } \\
\text { improved }\end{array}$ & $60.69 \%$ & $\begin{array}{l}\text { B3:I could see role } \\
\text { mode team has } \\
\text { influenced } \\
\text { confidence in other } \\
\text { teams } \\
\text { B5:On the whole } \\
\text { positive change is } \\
\text { seen in influence of } \\
\text { role model team in } \\
\text { building } \\
\text { Communication in } \\
\text { other teams }\end{array}$ & $\begin{array}{l}42.350 \% \\
63.536 \%\end{array}$ \\
\hline 3 & Multi Skill C1-C4 & $\begin{array}{l}\text { C2:learn and teach helps } \\
\text { in building self-respect }\end{array}$ & $68.268 \%$ & $\begin{array}{l}\text { C1: I could see } \\
\text { transfer by role } \\
\text { model team to } \\
\text { other teams on new } \\
\text { technical learnings } \\
\text { makes the team } \\
\text { members happy }\end{array}$ & $62.007 \%$ \\
\hline 4 & $\begin{array}{l}\text { Support by Mentor } \\
\text { D1- D4 }\end{array}$ & $\begin{array}{l}\text { D2:Mentor feedback } \\
\text { helped me in correcting } \\
\text { my gaps }\end{array}$ & $70.09 \%$ & $\begin{array}{l}\text { D3:Mentor } \\
\text { ( role model team ) } \\
\text { motivated the other } \\
\text { teams }\end{array}$ & $51.458 \%$ \\
\hline
\end{tabular}




\begin{tabular}{|c|c|c|c|c|c|}
\hline 5 & $\begin{array}{l}\text { Social interactions } \\
\text { E1-E3 }\end{array}$ & $\begin{array}{l}\text { E1:Weekly trekking } \\
\text { helped to understand } \\
\text { each other }\end{array}$ & 86.107 & $\begin{array}{l}\text { E1: I could observe } \\
\text { Weekly trekking } \\
\text { helped to } \\
\text { understand role } \\
\text { model teams and } \\
\text { other teams } \\
\text { E3:I could see } \\
\text { Leadership visits, } \\
\text { Visitors comments } \\
\text { and Audits } \\
\text { Participation helps } \\
\text { interaction with } \\
\text { Role model team } \\
\text { and other teams }\end{array}$ & $69.795 \%$ \\
\hline 6 & $\begin{array}{l}\text { Reward and } \\
\text { recognitions F1-F5 }\end{array}$ & $\begin{array}{l}\text { F5: Clean workplace } \\
\text { motivates me } \\
\text { F1: Presentation to } \\
\text { visitors motivated me }\end{array}$ & $84.72 \%$ & $\begin{array}{l}\text { F5:Role model } \\
\text { team has } \\
\text { influenced the } \\
\text { other teams that } \\
\text { Clean workplace } \\
\text { motivates all }\end{array}$ & $57.406 \%$ \\
\hline
\end{tabular}

\section{Findings and suggestions}

Role model team is effective and easy to implement. The risk and time taken to make the role model team competent is less.

Role model teams a special identification and the trainings should not stop, its suggested that one of member from role model teams should be leader and can be designated as $\mathrm{CHO}$ Chief Happiness officer. His role should be identifying new areas and avenues towards building the team to higher levels.

\section{THE FUTURE CHALLENGES AND RESEARCH POSSIBILITY}

Cross training and role model approach can be researched further, the variables can be modified or fine-tuned. Research can also be done how to make the role model team competent in shorter period of time. Study should be made how the role model team efforts are appreciated and helps them to grow in their organisation.

There are challenges too, what will continue to motivate the role model team, if the reward and recognition stops or there is change in company / environment, then how will this team sustain. Since it's a role model team every one look at the team and hence motivations and self-esteem of this team should always be high, how to retain?

\section{CONCLUSIONS}

Use of role model team is a approach which is effective and can be implemented in TPM excellence award plants.

The variable identified, experimented and researched are validated statistically and hence can be used to get better results, with always their scope of improving or modifying the variables to suit the company / Environment.

The role model teams have gained trust (A5)and which enabled them to have better team work, this has led satisfaction (A5) in themselves and a starter for effective cross trainings.

While building role model teams the communications (B5) levels improved, the role model team has influence (B3) other members in cross trainings and overall communication has improved (B5).

Learning and teaching (C2) is good combinations for easy implementation, this also helps in multi skill in technical trainings, this has gained respect in the teams and self-confidence.(C1).

Mentor feedback (D2) improves the team members and , this has motived (D3) team members and cross team members too.

Weekly trekking (E1) or get together and presentations to the leadership and visitors are key enablers and should be continued (E1,E3).

When the workplace $(\mathrm{F} 1, \mathrm{~F} 5)$ has transformed to clean and organized, it makes everyone working happy and motivated (F5), Role model team has influenced other team members and the chain reaction of training continues.

\section{REFERENCES}

[1] Abshiek, Rajbir, Harwinder, Total Productive Maintenance, Research gate, 2014.

[2] Kathleen, Roger \& Kristy, The impact of Total Productive maintenance on measuring performance, Elsevier, 1999.

[3] Van Mielro H, Self managing team work and psychological well being, Technische Universiteit Eindhoven, 2003.

[4] Jannes Slomp and Eric, Cross - training and team performance, Taylor and Franics, 2002.

[5] Steve, Work Groups and Teams in organisation, Cornell university, ILR School, 2001.

[6] Marks, Sabella,Burke, and Zaccro, The impact of cross training on team effectiveness, 2002.

[7] Kenneth \& David, Work team and effectiveness, Research gate, 1990.

[8] Shelly, Transformational leadership and team performance, Research gate, 2004 